Resumen por los autores, Waro Nakahara y James B. Murphy.

Sobre la naturaleza del llamado centro germinal en el tejido linfoide.

En una serie de estudios sobre la estimulación linfoide inducida artificialmente en varios animals han hallado los autores un marcado aumento en el número de figuras mitosicas en los centros germinales linfoides, el cual tiene lugar antes de la manifestación de la linfocitosis en la sangre, sin depender del método empleado para producir esta condición. Este paralelismo ofrece un apoyo experimental a la teoría original de Flemming, indicando la naturaleza linfoblástica de los llamados centros germinales de los órganos linfoides. Los métodos empleados para producir la estimulación linfoide fueron: 1) Inyección de tejido vivo homólogo seguido de inoculación de un tumor; 2) Expositión a una temperatura seca; 3) Exposición a una pequeña dosis de los rayos $X, y$ 4). Exposición a una pequeña dosis de los rayos $\mathrm{X}$ seguida de inoculación de un tumor.

Translation by José F. Nonidez Cornell Medical College, New York 
ACTHOR'S ABSTRACT OF THIS PAPER ISGUED

B T THE BIBLIOGRAPHIC GERVICE, JTLY 11

\title{
ON THE NATURE OF THE SO-CALLED GERM CENTER IN LYMPHOID TISSUE
}

\author{
WARO NAKAHARA AND JAMES B. MURPHY \\ The Rockefeller Institute for Medical Research \\ TWO FIGURES
}

INTRODUCTION

The lymphopoietic function of the spleen and lymph-nodes is a well-known fact, but as to just how the production of new lymphocytes is brought about in these organs is still a matter of uncertainty. Flemming ('85) first called attention to the frequent occurrence of mitosis in the tissue of lymphoid organs, especially at a certain spot in the follicle. To this spot he gave the name 'germ center,' believing it to be a birth-place of new lymphocytes. The view has been traditionally followed in numerous texts, in which the lymphoblastic nature of the cells of the germ center is generally accepted and is based entirely on the interpretation of the static 'picture' as observed in preserved material. On account of the obvious limitations of this method of observation, the deductions made on it lack finality.

In the course of experiments on various types of general lymphoid reaction, we have collected observations which may serve to throw additional light on the process. A résumé of the observations and a brief discussion bearing on them are given in this paper in the hope of elucidating somewhat the point under consideration.

\section{OBSERVATION}

Lymphoid reaction induced by dry heat

It was reported by Murphy and Sturm ('19) that animals subjected to a small exposure of dry heat (using an electric heating lamp as the source of heat) show, following a sharp initial fall, a 
rise of circulating lymphocytes often amounting to more than 200 to 300 per cent above the normal. Polymorphonuclear leucocytes participate in the fall, but they recover their normal level slowly and never rise above it.

Histological examination (Nakahara, '19) of the spleen and lymph-nodes of animals carried as a parallel to the above experiment showed that these organs, immediately after the heat treatment, contain numerous necrotic cells. The dead cells were present abundantly in the nodules and in the pulp of spleen, cortex, and lymph-cords of nodes. The cells of the germ centers were apparently unaffected, but cell division was totally suppressed.

It was also observed at about forty-eight hours after the treatment that, along with an elimination of the necrotic cells, there was an abnormally large number of mitotic figures present in the germ centers, and this hyperactivity of the centers continued for several days.

Lymphoid reaction in immunity to transplated cancer induced by an injection of homologous living tissue

Mice, as is well known, can be made relatively resistant to transplanted cancer by injecting them with an emulsion of homologous living tissue ten days before inoculating the cancer grafts. Murphy and Morton ('15) found that the lymphocytic elements of the blood showed an active increase during this process, while polymorphonuclear cells were not appreciably affected. No change in the lymphocytes occurred in the resistant mice until the cancer graft was introduced, when an immediate and sharp rise took place in these cells. In the majority of animals the increase was 100 to 200 per cent above the normal and endured about two weeks.

The histological study (Murphy and Nakahara, '20) made of preserved material from the inoculated and resistant mice showed in the germ centers of the lymphoid organs increase in mitotic figures, reaching a miximum about five days after the immunizing injection and followed by a fall, the normal being regained by the tenth day. The resistant mice when inoculated with a cancer 
graft ten days after the tissue injection show a second great increase in the mitotic figures, particularly of the germ centers. Judging from the number of mitosis, this second stimulation is more intense than the first.

\section{Lymphoid reaction induced by small doses of $x$-rays}

The selective action of X-rays on the lymphoid tissue has been recognized since the work of Heineke ('05). It was shown in this laboratory that while large doses of x-ray are destructive to, small doses bring about an increase in the lymphoid cells (Murphy and Morton, '15). In the case of rabbits thus treated, the number of circulating lymphocytes rose often in the course of one week (Thomas, Taylor, and Witherbee, '19) 100 per cent above the normal.

Histologically (Nakahara, '19) in these animals no appreciable destruction of cellular elements of spleen and lymph-nodes was observed; nevertheless the mitotic figures increased gradually in the germ centers, the height being reached in a few days after the treatment, and the increase persisted for a period of about two weeks.

Lymphoid reaction in immunity to transplanted cancer induced by small dose of $x$-rays in mice

Further, it was noted that in mice a certain small dose of x-rays of low penetration induces a stimulation of the lymphoid tissue (Nakahara and Murphy '20) and a regular and considerable increase in the number of mitotic figures of the germ centers takes place from twenty-four hours to four days after the treatment.

When cancer grafts were inoculated in these mice seven days after the x-ray treatment, an appreciable increase in resistance as compared to the normal untreated mice was detected (Nakahara and Murphy, '21). The blood picture of the mice, thus rendered comparatively more resistant, showed no constant change following the x-ray treatment, but the lymphocytes were found to rise 100 per cent or more above the normal within two weeks after can- 
cer-graft inoculation (Nakahara and Murphy, '21). As in other varieties of cancer immunity, the polymorphonuclear leucocytes showed no appreciable change.

There was some variation observed in the histological appearance of the lymphoid organs of mice first $\mathrm{x}$-rayed and inoculated with cancer grafts seven days afterward, but as a rule a profound acceleration of the rate of cell division was present in the lymphoid tissue, and especially in the area of germ centers (Nakahara and Murphy, '21).

\section{DISCUSSION}

The material which supplied the above data was studied primarily from the point of view of our interest in the relationship between the lymphoid cells and resistance to transplanted cancer in mice. In cancer immunity, induced by the usual means, namely, by the injection of living homologous tissue, it was noted that a marked increase in the circulating lymphocy tes occurs, with which is associated an increase of cell multiplication by mitosis in the germ centers of the lymphoid organs. This relationship between the resistance to cancer inoculation and lymphocytosis was observed, regardless of means by which the lymphocytosis is induced. The rise of the lymphocytes of the blood is invariably preceded by an increased proliferative cellular activity in the germ centers. These facts suggest that lymphoid germ centers are really made up of lymphoblastic tissue, and are among the sources of lymphocytes. The cells comprising the so-called germ centers and the lymphocytes making up the nodule of lymphoid organs are often stated to differ morphologically, but in reality there is no criterion which serves actually to distinguish one from the other.

The fact that phagocytosis sometimes occurs in the area of germ centers and is absent from the lymph-nodules may be urged as evidence that the cells of the germ center are not lymphoid in nature, as lymphocytes are non-phagocytic. Such a deduction would seem too dogmatic, since embryonic mesenchymal cells, from which lymphoid tissue develops, are admittedly phagocytic. Moreover, it would be difficult to decide whether the large cells containing ingested cell fragments (Flemming's 'stainable particles') 
really originate from the cells indigenous to germ centers or come from without. It is well known, also, that new lymphocytes are produced by a division of a preexisting one, which is capable of mitosis. This obviously cannot be considered as the only possible method of lymphocytic proliferation, as, embryologically, it is conceivable that cells with the potentiality of developing into lymphocytes may coexist in the adult along with the already differentiated lymphocytes.

\section{SUMMARY}

Several kinds of lymphoid reactions are described in which stimulation of the cell division of the germ centers of lymphoid organs preceded lymphocytosis in the blood. The association of the two processes described provides evidence that the lymphoid germ centers are in fact sources of blood lymphocytes, as the name indicates.

\section{LITERATURE CITED}

Fleming, W. 1885 Arch. f. mikr. Anat., Bd. 24, S. 355, 550.

Heineke, H. 1905 Mitt. Grenzgeb Med. u. Chir., Bd. 14, S. 21.

Murphy, James B., And Morton, J. J. 1915 Jour. Exp. Med., vol. 22, p. 204. 1915 Jour. Exp. Med., vol. 22, p. 800.

Murphy, James B., and Nakahara, W. 1920 Jour. Exp. Med., vol. 31, p. 1.

Murphy, James B., And Sturm, E. 1919 Jour. Exp. Med., vol. 29, p. 1.

Nakahar., W. 1919 Jour. Exp. Med., vol. 29, p. 17. 1919 Jour. Exp. Med., vol, 29, p. 83.

Nakahara, W., and Murphy, James B. 1920 Jour. Exp. Med., vol., 31, p. 13. 1921 Jour. Exp. Med., vol. 33.

Thomas, M. M., Taylor, H. D., and Witherbee, W. D. 1919 Jour. Exp. Med., vol. 29, p. 75 . 


\section{PLATE 1}

\section{EXPLANATION OF FIGURES}

1 A germ center of lymph-node of mouse treated with a small dose of x-rays of low penetration. Note the hyperactivity in cell proliferation as indicated by an unusually large number of mototic figures $(M)$. The majority of mice thus treated are potentially more resistant to transplanted cancer than untreated mice, and show, upon cancer inoculation, a marked increase in the number of circulating lymphocytes. $\times 480$.

2 An inactive germ center of lymph-node of mouse. Note the absence of mitotic figures. $\times 480$. 


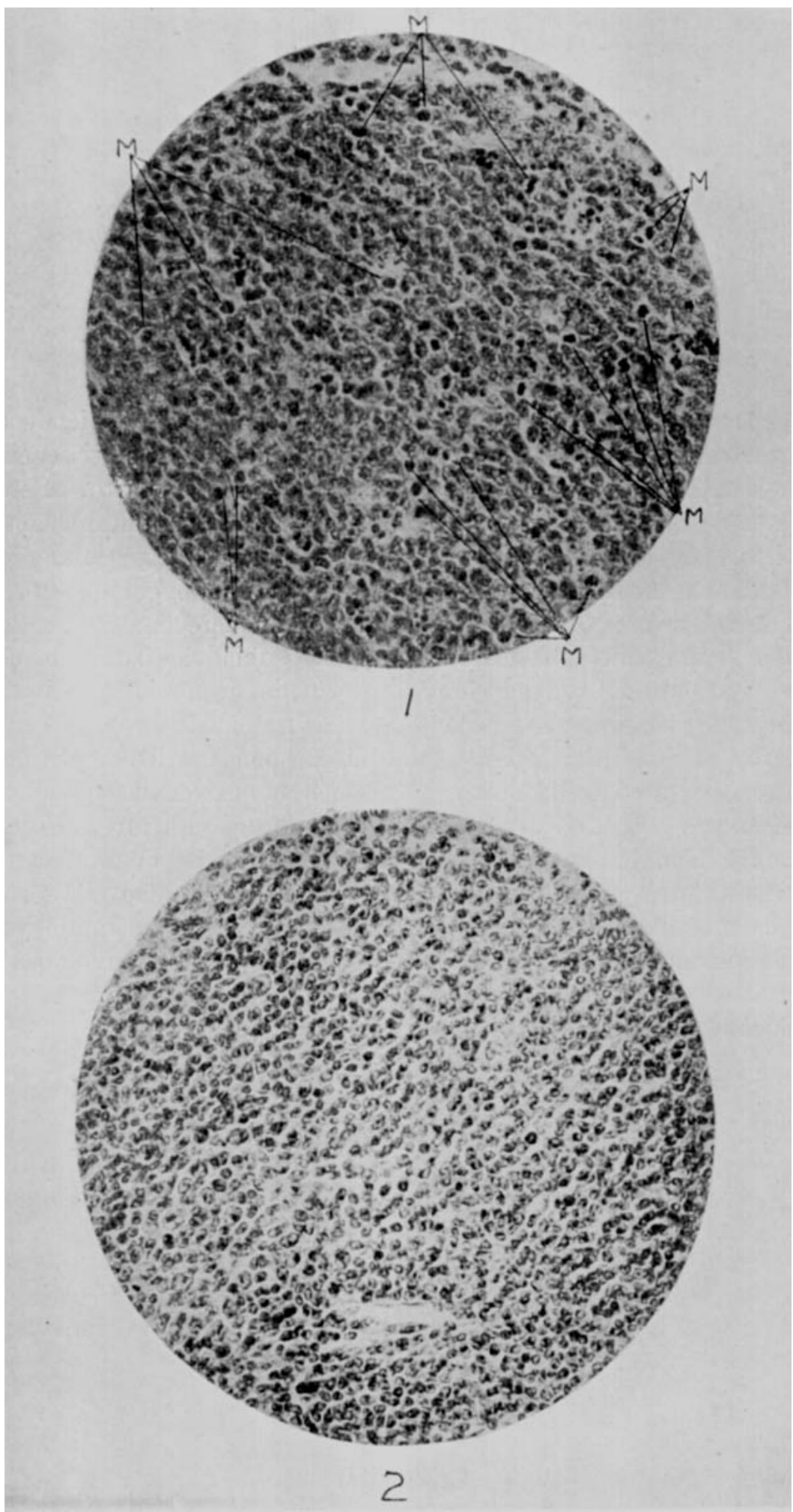

